
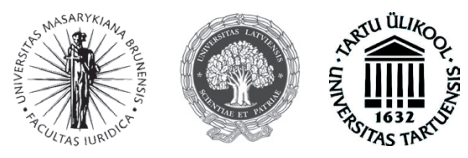

ISSN 1392-6195 (print) ISSN 2029-2058 (online) JURISPRUDENCIJA JURISPRUDENCE 2013, 20(3), p. 841-854.

\title{
EUROPOS SAJUNGOS TEISĖS IR TARPTAUTINĖS TEISĖS SANTYKIO KLAUSIMU
}

\author{
Saulius Katuoka \\ Mykolo Romerio universiteto Teisès fakulteto \\ Tarptautinès ir Europos Sajungos teisès institutas \\ Ateities g. 20, LT-08303, Vilnius, Lietuva \\ Telefonas (+370 5) 2714670 \\ Elektroninis paštas skatuoka@mruni.eu
}

Iteikta 2013 m. liepos 3 d., parengta spausdinti 2013 m. rugsèjo $20 \mathrm{~d}$.

doi:10.13165/JUR-13-20-3-02

Anotacija. Straipsnis skirtas aktualiam tarptautinès teisès ir Europos Sajungos teisès santykio klausimui. Konstatuojant, kad egzistuoja savarankiškos teisès sistemos, neišvengiamai kyla šiu teisès sistemu santykio bei sąveikos klausimas. Teisinëje literatūroje dviejü teisès sistemu santykio klausimas nagrinejamas ivairiais aspektais. Autorius pasirinko tokia straipsnio struktüra: pirmiausia aptariama bendroji tarptautinès teisès ir Europos Sajungos teisès santykio problema. Apibüdinant šia problema, pirmiausia nagrinëjamas Europos Sajungos teisès ir tarptautinès teisès pobüdis, šiu teisès sistemu išskirtiniai bruožai. Pateikiami Strasbūro Teismo ir Europos Sajungos Teisingumo Teismo sprendimai, kuriu pagrindu sprendžiama šiu teisés sistemu santykio problema. Antroje straipsnio dalyje aptariamos pagrindinès teorijos - monistine, dualistinè, koordinacine, kurios galètu büti pritaikytos sprendžiant dvieju. teisès sistemu: tarptautines teisès ir Europos Sajungos teisès, santykio klausima.

Reikšminiai žodžiai: Europos Sajungos teisè, tarptautinè teise, monistinè teorija, dualistine teorija, koordinacine teorija. 


\section{Ivadas}

Šiuolaikinis teisinis pliuralizmas pasireiškia įvairiomis formomis, tarp kurių ir egzistuojančios įvairios teisès sistemos. Šiuo metu galime konstatuoti, kad egzistuoja trys savarankiškos teisès sistemos: atskirų valstybių nacionalinès teisès sistema, tarptautinès teisès sistema ir Europos Sajungos teisès sistema. Kalbant apie šias sistemas, visų pirma, iškyla šių teisès sistemų santykio bei sąveikos problemos, kurias galima analizuoti aptariant atskirai nacionalinès teisès ir Europos Sajungos teisès, nacionalinès teisès ir tarptautinès teisės, tarptautinès teisės ir Europos Sajungos teisès konkrečias santykio problemas. Teisès doktrinoje kiek plačiau yra išnagrinètas nacionalinès teisès ir Europos Sajungos ar tarptautinès teisès santykio problemos. Mūsų žiniomis, tarptautinès teisès ir nacionalinès teisès santykio klausimu yra apginta nemažai disertacijų, parašyta monografijų ir mokslinių straipsnių. Yra net susiformavusios trys teorijos, kurios vienu ar kitu aspektu aiškina nacionalinės teisès ir tarptautinès teisès santykio bei sąveikos klausimus: monistinè, dualistinè ir koordinacinè. Ar gali šios teorijos būti pritaikytos, nagrinejjant Europos Sajungos teisès ir tarptautinès teisės santykį? Laiko prasme kur kas naujesnè ir kur kas mažiau studijuota tarptautinès teisès ir Europos Sajungos teisès santykio problema, todèl minètų teorijų pritaikymas aiškinant dviejų savarankiškų teisès sistemų santykị yra probleminis.

Tiesa, pastarajį dešimtmetị vis daugejja mokslinių darbų, skirtų tarptautinės teisès ir Europos Sajungos teisès santykio bei sąveikos problemoms spręsti. Kadangi pati problema yra kompleksiné, ji struktūriškai gali būti nagrinèjama ịvairiais aspektais. Pavyzdžiui, vokiečių mokslininkas daktaras Heiko Saueris, tyrinėdamas tarptautinès teisès ir Europos Sajungos teisès santykị, iškelia problemas ir jas struktūriškai analizuoja, tirdamas bendrą dviejų teisės sistemų problemą, toliau analizuoja Europos Sajungos teisès ir tarptautinių sutarčių santykio problemas, ir galų gale skiria dèmesį Europos Sajungos žmogaus teisių chartijos ir Žmogaus teisių bei pagrindinių laisvių apsaugos konvencijos santykio bei sąveikos analizei ${ }^{1}$.

Tačiau pagrindinis klausimas, kurị nagrinèja H. Saueris, yra teismų ar tribunolų jurisdikcijų taikymas, sprendžiant ginčą, kilusị tarp atskirų teisinių sistemų. H. Saueris pasisako už tai, kad jurisdikcinių konfliktų tarp nacionalinių teismų, Europos bei tarptautinių teismų turètų būti išvengta. To tikslo realizavimui H. Saueris siūlo taikyti trijų žingsnių metodą. Pirmasis žingsnis galètų būti realizuojamas taikant maksimalų institucinio bendradarbiavimo metodą, pavyzdžiui, prašant priimti preliminarų sprendimą. Antrasis žingsnis - susijęs su teismo, kuris galètu spręsti ginčą, paieška. Remiantis forum conveniens doktrina, pasirenkamas tas teismas, kuris yra arčiausiai ginčo šalių, t. y. tinkamiausias teritoriniu požiūriu. Trečiasis žingsnis - siejamas su pareigos vengti konflikto realizavimu, sprendžiant ginčą būtina vadovautis lojalumo ir santūrumo principu².

1 Sauer, H. Jurisdiktionskonfl ikte in Mehrebenensystemen: DieEntwicklung eines Modells zur Lösung von Konfl ikten zwischen Gerichten unterschiedlicher Ebenenin vernetzten Rechtsordnungen. Heidelberg: Springer, 2007.

2 Plačiau apie H. Sauerio monografiją žr. dr. Nikolaos Lavranos atsiliepimą, EJIL. Book Reviews. 2008, p. 875-878. 
Per pastaruosius penkerius metus pasirodė mokslinių darbų tarptautinès teisès ir Europos Sajungos teisès santykio tema, kuriuos parengė Prancūzijos mokslininkai. Antai dar 2011 metais vasario mėnesị, Paryžiuje buvo organizuota konferencija tema „Europos Sajungos teisè ir tarptautinè teisė: teisiniai sąveikos pagrindai“. Nemažai darbų bendra tarptautinès teisès ir Europos Sajungos teisès tematika yra parašęs Paryžiaus universiteto profesorius Žanas Silvestras Beržè. Profesorius nagrinėja tiek bendrą ES ir tarptautinès teisès sąveikos problemą, tiek kitus konkrečius klausimus. Jo darbuose ypač skiriama dėmesio šių dviejų teisès sistemų normų taikymo bendrame kontekste bei normų taikymo teismuose problemoms nagrinėti ${ }^{3}$.

\section{Bendroji tarptautinės teisės ir Europos Sąungos teisės santykio problema}

Pirmiausia nagrinèsime bendrąą tarptautinès teisès ir Europos Sajungos teisès santykio problemą. Po to sutelksime dėmesị ị teorijų, aiškinančių teisés sistemų santykị bei sąveiką, analizę. Išnagrinèsime monistinę, dualistinę bei koordinacinę teorijas bei galimą jų pritaikomumą, aiškinant tarptautinès teisès ir Europos Sajungos teisès santykį.

Pirmiausia pamėginsime panagrinèti bendrą tarptautinès teisès ir Europos Sajungos teisès santykio problemą. Norint ịsigilinti ir suvokti šią problemą, būtina aptarti Europos Sajungos teisés ir tarptautinès teisès prigimtį. Nepaisant fakto, kad Europos Sajungos teisè yra kildinama iš tarptautinès teisès, tolesnè šios teisès sistemos raida patvirtina faktą, kad Europos Sajungos teisė vystosi kaip savarankiška teisės sistema. Faktą apie Europos Sajungos teisès sistemos savarankiškumą patvirtino Europos Sajungos Teisingumo Teismas dar 1963 metais Van Gend en Loos byloje nurodydamas, kad „(...) Bendrija sukūrè naują teisinę tvarką, kurios naudai valstybės apribojo savo suverenias teises ir kurios subjektai yra ne tik valstybės, bet ir jų piliečiai. Bendrijos teisè nustato ne tik pareigas individams, bet ji skirta ir tam, kad suteiktų jiems teises, kurios tampa jų teisinès sistemos dalimi. Šios teisès atsiranda ne tik tada, kai jas aiškiai suteikia sutartis, bet ir tada, kai jos išplaukia iš sutarties, aiškiai nustatomų issipareigojimų individams, taip pat valstybėms narèms bei Bendrijos institucijoms. ${ }^{\text {"4 }}$

Europos Sajungos teisès prigimtis išryškinama terminu viršnacionalinė teisè. Šiuo terminu nusakomas dviejų teisès sistemų - ES teisès ir nacionalinès teisès santykis. Europos Sajungos teisès viršenybe nacionalinės teisès atžvilgiu - vienas iš pagrindinių ES teisès principų ${ }^{5}$. Šis principas yra patvirtintas Europos Sajungos Teisingumo Teismo praktikos $^{6}$, taip pat atsispindi ES valstybių narių nacionaliniuose teisès aktuose. Antai,

3 Berg'e, J.-S. L'aplication die droit de l'lenion europenne et du droit international: de l'aplicabilite' a e 'invocabilite.

4 Cituojama pagal Vadapalas,V. Tarptautinè teisè. Vilnius: Eugrimas, 2006, p. 50.

5 Jarukaitis, I. Europos Bendrijų teisès viršenybė ir valstybių narių bei Lietuvos Respublikos teisè. Teise். 2000, 37: 46 .

6 Europos Sajungos teisès viršenybès principas pirmą kartą suformuluotas byloje Costa v. ENEL. Case (6/64) Costa v. ENEL [1964] ECR 585. 
2004 m. liepos 13 d. buvo priimtas Lietuvos Respublikos konstitucinis aktas „Dèl Lietuvos Respublikos narystès Europos Sajungoje“. Šio akto 2 punkte nurodoma, kad jei tai kyla iš sutarčių, kuriomis grindžiama Europos Sajunga, Europos Sajungos teisès normos Lietuvos Respublikoje taikomos tiesiogiai, o teisės normų kolizijos atveju jos turi viršenybę prieš Lietuvos Respublikos įstatymus ir kitus teisès aktus. Atkreiptinas dèmesys, kad šiame akte kalbama apie sutartis, kuriomis grindžiama Europos Sajunga. Dar labiau sukonkretinant, galima pasakyti, kad kalbama apie Europos Sajungos pirminès teisès šaltinius - steigimo sutartis.

Norètume atkreipti dėmesį, kad viršnacionalinis Europos Sajungos teisès pobūdis pasireiškia tik vidiniuose santykiuose. Turime galvoje santykius tarp Europos Sajungos ir nacionalinių valstybių - Europos Sajungos narių. Todèl manytume, kad kalbant apie tarptautinès teisès ir Europos Sajungos teisès sistemų santykị, Europos Sajungos teisès viršnacionalinis pobūdis nèra esminis šios sistemos bruožas.

Konstitucinio Teismo teisejjas daktaras Zenonas Namavičius, analizuodamas šio Konstitucinio akto 2 punkto nuostatą, kelia klausimą dèl Europos Sajungos antrinès teisès aktų tiesioginio taikymo Lietuvoje ir šios nuostatos suderinamumo su Lietuvos Respublikos Konstitucijos 7 straipsnio nuostata, kad negalioja joks įstatymas ar kitas aktas, priešingas Konstitucijai. Autorius daro išvadą, kad ES antrinès teisės normos, kaip nesusijusios su Lietuvos teisèkūra, sudedamaja Lietuvos teisinès sistemos dalimi lyg ir nelaikytinos, jos tartum nepriklauso vidaus teisès šaltiniams ${ }^{7}$. Nesigilindami plačiau ị keliamą problemą, nes ji tik iš dalies susijusi su mūsų nagrinèjama tema, galime pasakyti, kad Lietuvos Respublikos teisinejje praktikoje ši problema nebuvo iškilusi, reglamentai yra tiesiogiai taikomi Lietuvos teisineje sistemoje. Direktyvos, skirtingai negu reglamentai, nèra tiesioginio taikymo teisès aktas, o tai reiškia, kad direktyva turi būti perkelta ị Lietuvos teisès sistemą. Direktyvos perkèlimą ị Lietuvos teisę koordinuoja Europos teisès departamentas prie Lietuvos teisingumo ministerijos.

Koks tarptautinès teisès kaip savarankiškos teisès sistemos pobūdis bei pagrindiniai ypatumai?

Tarptautinè teisė turi daugeli specifinių požymių, leidžiančių ją atriboti nuo nacionalinių teisès sistemų ar nuo Europos Sajungos teisès. Profesorius V. Vadapalas, apibūdindamas tarptautinę teisę, pažymi, kad šioje teisès sistemoje nèra vienos ịstatymų leidimo valdžios, egzistuoja tarptautinès teisès šaltinių ypatybès, nėra centralizuotos vykdomosios valdžios bei bendros privalomos kompetencijos teismo, specifiniai subjektai, specifinès tarptautinès teisès normų kūrimo ypatybès ${ }^{8}$.

Tarptautinès teisès sistemoje susiformavo ir specifiniai tarptautinès teisès principai $^{9}$. Vienu iš svarbiausių tarptautinès teisès principų laikomas valstybių suverenios lygybès principas. Šiuo principu turi vadovautis visos valstybès, šiuo principu grindžiama vienos iš masiškiausių tarptautinių organizacijų - JTO veikla. Visos valstybès nepri-

7 Namavičius, Z. Suverenitetas ir Europos Sajungos teisė [interaktyvus]. [žiūrèta 2013-03-18]. <http:// www.lrkt.lt/PKonferencijose07.pdf $>$.

8 Vadapalas, V., supra note 4, p. 22-35.

9 Tarptautinès teisès principas suprantamas kaip vadovaujantis pradas, parodantis tarptautinès teisès esmę bei vystymosi perspektyvas. 
klausomai nuo jų dydžio, nuo ekonominio potencialo, vadovaujantis šiuo principu yra lygios teisine prasme. Net ir tarptautinès teisès normos sukūrimas yra grindžiamas kiekvienos valstybès suverenia valia.

Tarptautinės teisès esmę atskleidžia principas, draudžiantis tarptautiniuose santykiuose grasinti jèga ar naudoti jègą prieš bet kurios valstybès teritorinį vientisumą ar politinę nepriklausomybę. Karas kaip politikos ịgyvendinimo priemonė tarptautinėje teisejje yra uždraustas. Todèl pagal savo esmę tarptautinè teisė traktuojama kaip teisès sistema, kuria užtikrinama taika ir visuotinis saugumas. Svarbus ir kitas tarptautinès teisės principas, ịpareigojantis tarptautinès teisès subjektus ginčus spręsti tik taikiomis priemonèmis, nesiekiant pavojaus taikai ir saugumui.

Valstybių kaip pagrindinių tarptautinės teisès subjektų savarankiškumą užtikrina principas, draudžiantis kištis ị reikalus, kurie priklauso valstybių vidaus jurisdikcijai. Egzistuoja ir kiti tarptautinès teisès principai, kurie sudaro tarptautinès teisés pagrindą ir apibūdina tarptautinę teisę kaip tokią. Apibendrintai galima pasakyti, kad tarptautinè teisė yra konsensualinio ir koordinacinio pobūdžio teisès sistema. Todẻl kalbèti apie viršnacionalinị šios teisès pobūdị taip pat nebūtų teisinga.

Tarptautinè teisė negali būti suprantama abstrakčiai, ji turi būti aiškinama atsižvelgiant $i \mathfrak{i}$ istorinị, kultūrinị ir politinị kontekstą. Ypač glaudus ryšys tarp tarptautinès teisès ir politikos. Tarptautinè teisė, kaip pažymi profesorius V. G. Vitctumas, pasireiškia kaip priemonè, formuojanti politiką bei nustatanti politikos kryptis bei ribas ${ }^{10}$.

Mūsų nuomone, išryškintų tarptautinès teisès požymių visuma, apibūdina tarptautinès teisès sistemą kaip savarankišką, egzistuojančią greta kitų teisès sistemų. Jei santykyje su kitomis teisès sistemomis šie tarptautinès teisès požymiai būtų ignoruojami, būtų pažeistas šios teisès sistemos autonomiškumas ir jos normomis nustatyta teisètvarka. Galima teigti, kad šiuolaikinèje tarptautinèje teisejje susiformavo gana pažangios ir reikšmingos teisinio reguliavimo kryptys: visų pirma, tarptautinè teisé imperatyviai reikalauja taikios tarptautinių santykių dinamikos, antra, tarptautinė teisé užtikrina tiek universalios, tiek regioninès žmogaus teisių apsaugos standartus, trečia, tarptautinè teisè, nustatydama tarptautinius bendradarbiavimo pagrindus, ženkliai prisideda prie globalinių problemų sprendimo. Šiose tarptautinio turinio reguliavimo srityse egzistuoja tarptautiniai standartai, todèl susidūrus su kitomis teisès sistemomis šių standartų pažeisti nevalia. Kitos teisès sistemos, susidūrusios su tarptautine teise, gali nustatyti aukštesnius arba adekvačius, pavyzdžiui, žmogaus teisių srityje, standartus. Žemesni standartai neįmanomi, jei tarptautinès organizacijos ar valstybès yra prisièmusios tarptautinius ịsipareigojimus vienoje ar kitoje tarptautinio reguliavimo srityje.

Atskirų teisès sistemų susidūrimas dažnai išryškèja teismų darbe. Reikia pasakyti, kad būtent tada neretai formuojasi skirtinga teismų praktika, pasireiškianti skirtingu teisès normų interpretavimu, o neretai to paties pobūdžio ginčuose priimamais skirtingais sprendimais.

Kaip pažymi Žmogaus Teisių Teismo teisẻja daktarẻ Danutė Jočienė, dviejų teismų - Europos Sajungos Teisingumo Teismo ir Strasbūro Teismo - praktikoje „skirtingu 
teisių ir jų apimties aiškinimo ribų išvengti nepavyksta“"11. Tačiau paskutinès tendencijos mums leidžia konstatuoti, kad būtent tarp šių dviejų teismų jiems aktyviai bendradarbiaujant vyksta tam tikras koordinacijos procesas. Teigiamą pavyzdi šioje srityje rodo Strasbūro Teismas, vystydamas teorinius pradmenis bei priimdamas kompromisinio pobūdžio sprendimus. Eidamas ne konflikto, o derinimo keliu Strasbūro Teismas prièmė keletą sprendimų, kardinaliai paaiškinančių sudėtingą žmogaus teisių apsaugos klausimą per Europos Sajungos teisès bei Žmogaus teisių ir pagrindinių laisvių apsaugos konvencijos santykio prizmę. Pirmiausia, Strasbūro Teismas byloje Bosphorus prieš Airiją išvystė tapačios / adekvačios žmogaus teisių apsaugos doktriną dviejose Europos Sajungos teisès ir Europos regioninès žmogaus teisių apsaugos teisès sistemose (Bosphorus bylos sprendimo 155 paragrafas). Kaip pažymi D. Jočienė, Strasbūro teismo koridoriuose ši byla dažnai apibūdinama kaip šio Teismo ir Europos Sajungos teismų taikos sutartis $^{12}$. Ši byla patvirtino faktą, kad abi teisès sistemos, abu teismai igyvendina tinkamą, tuo metu egzistuojančią adekvačią žmogaus teisių apsaugą ir todėl konfliktų tarp teisès sistemų ir teismų neturètų egzistuoti.

Platesniu aspektu tarptautinès teisès ir Europos Sajungos teisės santykis buvo aptartas 2012 m. spalio 16 d. Europos Sajungos Teismo sprendime „Dėl valstybès vadovo statuso"13. Ginčas kilo tarp Vengrijos ir Slovakijos, dèl Vengrijos prezidento vizito i Komarno miestą. Teismo sprendime buvo konstatuota, kad egzistuoja dvi savarankiškos teisès sistemos, turinčios savo reguliavimo dalyką. Buvo pabrèžta, kad Europos Sajungos teisès reguliavimo laukas yra siauresnis, lyginant su tarptautine teise, pavyzdžiui, diplomatiniai santykiai yra ne Europos Sajungos teisès, o tarptautinès teisés reguliavimo dalykas. Taip pat buvo pasakyta, kad geros kaimynystès santykių principas gali būti taikomas tiek Europos Sajungos teisèje, tiek tarptautinèje teisèje $\mathrm{e}^{14}$.

\section{Teorijų, aiškinančių tarptautinès ir nacionalinės teisės santykị, pritaikymas sprendžiant tarptautinès teisés ir Europos Sąjungos teisès santykio klausimą}

Būtinybė kurti teorijas, aiškinančias ịvairių teisès sistemų santykị, atsirado susiformavus atskiroms teisès sistemoms ir atsiradus poreikiui tinkamai taikyti šių teisès sistemų normas. Pačios teorijos teisės doktrinoje nėra savitikslès. Teorijos ir vertinamos tiek, kiek padeda išspręsti konkrečias problemas. Teorijos laikui bėgant dažniausiai tikslinamos, įvedant naujus teorinius teiginius, atsižvelgiant ị gyvenimo realijas. Kadangi anksčiausia susiformavo nacionalinès teisès sistemos ir tarptautinè teisè, tai pirmiausia

11 Jočienè, D. Pagrindinių teisių apsauga pagal Europos žmogaus teisių konvenciją ir Europos Sajungos teisę. Jurisprudencija. 2010, 3(121): 17.

12 Ibid., p. 107.

13 L'arret Hongrie c. Republique Slovaque du 16 October 2012, Affaire c.-364/10.

14 Plačiau apie šią bylą žr. Aloupi, N. Les reports entredroit international et droit de L'union europenne. A propos du statut du chef d'Etat membre au regard de l'arret Hogrie c. Republique Slovaque du 16 Octobre 2012. Revue generale de Droit international public. Tome CXVII. 2013, p. 7-35. 
ir atsirado teorijos, kurių pagrindu buvo bandoma aiškinti šių dviejų teisės sistemų santyki.

Baziniai teiginiai, kurių pagrindu buvo aiškinamas santykis tarp tarptautinès teisès ir nacionalinès teisès, pirmiausia buvo suformuluoti Anglijoje lordo Čanseloro Talboto. Lordas teiginiu, kad tarptautinè teisè yra bendrosios teisès (Common Law) dalis, tarsi padèjo pagrindus monistinei teorijai ${ }^{15}$. Laikui bėgant susiformavo trys teorijos, aiškinančios tarptautinès teisès ir nacionalinès teisès santykị: monistinė, dualistinė, koordinacinè. Pabandysime trumpai apibūdinti šias teorijas.

Kaip teigia profesorè Lyra Jakulevičienė, istoriškai monizmas grindžiamas Emanuelio Kanto filosofija apie teisès vienybès koncepciją: tarptautinè ir nacionalinè teisé yra vieno vientiso „kūno“, žinomo kaip „teisé“, komponentai ${ }^{16}$. Monistai, pasisakydami už vieningą teisès sistemą, suranda ir filosofinị pagrindimą, patvirtinantị sistemos vieningumą teiginiu, kad šios sistemos kūrëjas yra vienas - valstybė. Monistai savo ruožtu skyla ị dvi stovyklas pagal tai, kam suteikiamas primatas kolizijos atveju: vieni suteikia pirmenybę (ir tokių yra dauguma) tarptautinei teisei, kiti - nacionalinei teisei. Čekija, Nyderlandai, Rusija, Prancūzija - tai valstybès, kurios laikosi monistinès teorijos. Monistinės teorijos, mūsų nuomone, laikosi ir Lietuvos Respublika. Kaip pažymi profesorius V. Vadapalas, norminiu pagrindu, leidžiančiu Lietuvą priskirti prie monistinio modelio, yra Lietuvos Respublikos Konstitucijos 138 straipsnio 3 dalis, nustatanti, kad tarptautinès sutartys, kurias ratifikavo Lietuvos Respublikos Seimas, yra sudedamoji Lietuvos Respublikos teisinès sistemos dalis ${ }^{17}$.

Dualistinè teorija remiasi Hegelio mintimi, kad teisè - tai suverenumo aktas; nacionalinė teisè skiriasi nuo tarptautinès teisès; nacionalinė teisė galioja valstybès teritorijoje $^{18}$. Dualistiné teorija grindžiama teze, kad nacionaliné teisé ir tarptautiné teisé egzistuoja ir funkcionuoja atskirai. Egzistuodamos atskirai jos tarp savęs nesusisiekia, dèl to konfliktų tarp jų neturètų kilti. Norint ịgyvendinti tarptautinės teisès normą dualistinį modelị pripažistančioje valstybèje reikètų priimti nacionalinį teisès aktą. Dualistinès valstybės pavyzdžiais galètų būti Jungtinè Karalystė, Suomija, Italija, Vokietija.

Monistinès ir dualistinès teorijų dichotomija buvo išsklaidyta susiformavus koordinacinei teorijai. Šios teorijos pradininkas Džeraldas Ficmoris dar XX amžiaus viduryje aiškino tarptautinès teisès ir nacionalinės teisės santykị per šių sistemų suderinamumo prizmę $^{19}$. Ši teorija atspindejo to meto realijas, nes valstybè, prisiimdama tarptautinius įsipareigojimus, privalèjo suderinti juos su nacionaline teise. Nacionalinè teisè turi prisiderinti prie tarptautinès teisès, jei valstybė savo tarptautinius įsipareigojimus pripažísta teisiškai reikšmingais. Pavyzdžiui, remiantis Lietuvos Respublikos tarptautinių sutarčių įstatymo 4 straipsniu ,Sprendimų dẻl Lietuvos Respublikos tarptautinių sutarčių sudarymo tikslingumo prièmimas“, priimant sprendimą dèl Lietuvos Respublikos tarptautinès sutarties tikslingumo turi būti apsvarstyta, ar šios sutarties projekto nuostatos atitinka

15 Victum, V. G., et al., supra note 10, s. 126.

16 Jakulevičienè, L. Tarptautiniu sutarčiu teisè. Vilnius: Registrų centras, 2011, p. 381.

17 Vadapalas, V., supra note 4, p. 61.

18 Jočienè, D. Europos žmogaus teisių konvencijos taikymas. Vilnius: Eugrimas, 2001, p. 28.

19 Brounli, Ja. Mezdunarodnoje pravo. Kniga pervaja. Moskva, 1977, s. 69. 
Lietuvos Respublikos Konstituciją, Lietuvos Respublikos užsienio politikos ir nacionalinio saugumo pagrindus ir tikslus. Minèto įstatymo 7 straipsnis, nurodantis, kokios sutartys turi būti ratifikuotos, nustato reikalavimą, kad turi būti ratifikuotos tarptautinès sutartys, nustatančios kitokias teisès normas negu galiojantys Lietuvos Respublikos įstatymai. Neretai pačiose tarptautinėse sutartyse fiksuojamas reikalavimas suderinti nacionalinę teisę su tarptautiniais įsipareigojimais. Kaip pažymi profesorius V. Vadapalas, šiuolaikinėje tarptautinejje praktikoje vis daugèja tarptautinių sutarčių, kurios įpareigoja valstybes suderinti savo nacionalinès teisès nuostatas su tarptautiniais įsipareigojimais ${ }^{20}$.

Ar gali mūsų paminètos teorijos būti pritaikytos sprendžiat tarptautinès teisès ir Europos Sajungos teisès klausimą? Remdamiesi šių teorijų baziniais teiginiais, nacionaliniais, Europos Sajungos bei tarptautinès teisès šaltiniais ir teismų praktika, bandysime atsakyti ị ši klausimą.

Lietuvos Respublikos Konstitucinio akto „Dèl Lietuvos Respublikos narystès Europos Sajungoje“ 2 straipsnyje nurodoma, kad „Europos Sajungos teisès normos yra sudedamoji Lietuvos Respublikos teisinès sistemos dalis“. Šiuo teiginiu tarsi patvirtinama monistinè teorija, kurios pagrindinè tezè yra apie tai, kad egzistuoja vieninga teisès sistema. Iš tikrujų monistinè teorija, kurios pagrindinė tezė remiasi vieningos teisès sistemos egzistavimo faktu, buvo kritikuota teisès doktrinoje. Kritikuota dèl to, kad visiems akivaizdus faktas, kad egzistuoja savarankiškos, skirtingos teisès sistemos - nacionalinė teisè ir Europos Sajungos ar tarptautinè teisè, yra ignoruojamas ir neatitinka realios tikrovès.

Mūsų nuomonè dèl šios teorijos, atsakant ị klausimą dèl vieningos sistemos, būtų kontroversiška: ir taip, ir ne. Manytume, kad teiginiai apie dviejų sistemų vieningumą ar savarankiškumą turi būti patikslinti, pasakant, kokiu aspektu teiginys yra vartotinas. Matyt, kad niekam nekyla abejonių, kad yra susiformavusios nacionalinè teisès sistema, tarptautinès teisès sistema ir Europos Sajungos teisès sistema. Kai kalbama apie šias teisès sistemas, šių sistemų savarankiškumas ir savitumas yra patvirtintas tiek teisès doktrinos atstovų, tiek teisminès praktikos.

Tačiau kai konkreti valstybė pasirašo tarptautinę sutartị ar tampa, pavyzdžiui, Europos Sajungos nare, iškyla klausimas, kaip šios valstybès viduje bus taikomi kitos teisès sistemos aktai. Tą klausimą turi spręsti konkreti valstybė. Pavyzdžiui, Lietuvos Respublika šią problemą tarptautinių sutarčių atžvilgiu išsprendè pagrindiniame įstatyme - Konstitucijoje. Konstitucijos 138 straipsnyje nurodoma, kad ,tarptautinės sutartys, kurias ratifikavo Lietuvos Respublikos Seimas, yra sudedamoji Lietuvos Respublikos teisinès sistemos dalis“. Taigi, Lietuvos valstybè, prisièmusi tarptautinius įsipareigojimus, tarptautinès teisès normas igyvendina savo valstybės viduje, nurodydama, kad jos yra nacionalinès teisès sistemos dalis. Apie kitų teisès sistemos normų - Europos Sajungos ar tarptautinès teisès normų - vienybę nacionalinèje teisèje galime kalbèti tik taikymo prasme. Būtent taikymo prasme galima kalbėti apie vieningą teisès sistemą valstybės viduje ir kartu apie monistinę teoriją. Minėtas Konstitucinis aktas, kaip jau 
buvo minèta, sudaro galimybę per vieningos teisès sistemos prizmę taikyti ir Europos Sajungos teisès aktus.

Ar gali monistinès teorijos pagrindai būti taikomi aiškinant Europos Sajungos teisès ir tarptautinès teisès santykį? Manytume, kad atsakymas ị ši klausimą būtų teigiamas. Šiam teiginiui galima surasti ir tam tikrų teisinių argumentų. Visų pirma, šiuo klausimu egzistuoja gausi Europos Sajungos Teisingumo Teismo praktika. Praktika dèl monistinès teorijos taikymo būtų gana plati. Visų pirma, Europos Sajungos Teisingumo Teismas byloje Costa v. ENEL yra nurodęs, kad valstybès viduje gali egzistuoti vieninga Europos Sajungos ir nacionalinès teisès sistema, kai Europos Sajungos teisés normos taikomos tiesiogiai ${ }^{21}$. O byloje Haegeman v. Belgijos valstybé Europos Sajungos Teisingumo Teismas, analizuodamas Europos Sajungos sudarytas tarptautines sutartis su trečiosiomis valstybėmis ar tarptautinèmis organizacijomis, nurodè, kad tarptautinès sutartys yra integrali Europos Sajungos teisinès sistemos dalis ${ }^{22}$. Svarbus ir antras momentas, ị kurị Teismas dėmesị atkreipė jau kitoje byloje, Europos Sajungos sudaryti tarptautiniai susitarimai turi viršenybę Sajungos antrinės teisės aktų atžvilgiư ${ }^{23}$.

Ar gali būti taikomi dualistinès teorijos pagrindai, aiškinant tarptautinès teisès ir Europos Sajungos teisès santykį? Atsakymas teigiamas, tačiau tik iš dalies. Matyt, kad išeitinè pozicija, sprendžiant šių teisès sistemų santykio problemą, būtų teiginys apie dviejų autonominių, savarankiškų teisès sistemų egzistavimą. Antroji pozicija, kuria privalome remtis, aiškindami dviejų teisès sistemų santykį, yra ta, kad ES teisè negali būti subordinacinio pobūdžio teisė santykyje su tarptautine teise. Pripažindami šiuos du teiginius pagrịstais, mes galime pritarti dualistinès teorijos, teigiančios apie dviejų teisès sistemų, Europos Sajungos teisès ir tarptautinès teisès, autonomiją ir savarankiškumą, egzistavimui.

Tačiau dualistų teorijos atstovų teiginiui, kad tarp atskirų teisés sistemų nèra sąveikos, kad jos, kaip Rytai ir Vakarai, niekada nesusisiekia, mes negalètume pritarti kalbėdami apie tarptautinès teisès ir Europos Sajungos teisès santykị. Šių sistemų savarankiškumas nereiškia šių sistemų izoliacijos, - pažymi A. Mamontovas ${ }^{24}$. Europos Sajunga yra visateisis tarptautinès teisès subjektas. Subjektas, kuris įsipareigojo laikytis daugybės vadinamųjų mišrių sutarčių ${ }^{25}$. Pagal šias sutartis Europos Sajunga tapo atsakinga už tarptautinę teisètvarką, kuri kuriama visos tarptautinės bendrijos. Pavyzdžiui, Europos Sajunga tapo 1982 m. Jūrų teisès konvencijos šalimi 1998 m. balandžio 1 d. Šiuo metu šios konvencijos šalimis yra 165 valstybės.

Sutarties dèl Europos Sajungos veikimo 3 straipsnio 2 dalyje nurodyta, kad Sajunga naudojasi išimtine kompetencija tarptautiniams susitarimams sudaryti, kai jų sudarymas yra numatytas Sajungos ịstatymo galią turinčiame akte arba yra būtinas, kad Sajunga

21 Case (6/64) Costa v. ENEL [1964] ECR 585.

22 Byla 181/73 Haegeman v. Belgijos valstybe [1974] ECR 449, paras 5,6.

23 Byla C 344/04 IATA ir ELFAA [2006] Rink. 1-403, para 35.

24 Mamontovas, A. Tarptautinių sutarčių bei ES teisès kolizijų sprendimas Europos Teisingumo Teismo praktikoje: teisiniai aspektai. Socialiniu mokslu studijos. 2011, 3(1): 349.

25 Terminu ,mišrios sutartys“ apibrèžiamos tarptautinès sutartys, kurių šalimis yra Europos Sajunga, Europos Sajungos valstybės bei valstybès, kurios nėra Europos Sajungos narès. 
galètų naudotis savo vidaus kompetencija. Sajunga gali sudaryti tarptautinę sutartị su viena ar keliomis trečiosiomis šalimis arba tarptautinėmis organizacijomis - pažymima minètos sutarties 216 straipsnyje.

Europos Sajungos sutartyje dèl Europos Sajungos veikimo galime pastebèti kai kurių koordinacijos teorijos elementų. Antai Sutarties 218 straipsnyje nurodyta, kad valstybė narè, Europos Parlamentas, Taryba ar Komisija gali gauti Teisingumo Teismo nuomonę dèl to, ar numatytas susitarimas yra suderinamas su Sutarčių nuostatomis. Jei Teismo nuomonė yra neigiama, numatytas susitarimas negali ịsigalioti, jei jis nėra iš dalies keistas arba Sutartys nèra peržiūrètos. Tarptautinių sutarčių sudarymo srityje plačius iggaliojimus turi Taryba. Taryba leidžia pradèti derybas, priima derybinius nurodymus, leidžia pasirašyti ar sudaryti susitarimus. Be to, Taryba gali priimti sprendimą dèl tam tikros kategorijos tarptautinių sutarčių sudarymo tik gavusi Europos Parlamento pritarimą. Pavyzdžiui, Europos Parlamento pritarimas bus būtinas priimant sprendimą dèl Sajungos prisijungimo prie Europos žmogaus teisių ir pagrindinių laisvių apsaugos konvencijos. O Taryba turès prisijungimo prie Konvencijos klausimą spręsti vieningai. Visos tarptautinių sutarčiu sudarymo taisyklès patvirtina faktą, kad tarptautinès sutarties nuostatos turi būti derinamos su Europos Sajungos teisès aktais. Ir jeigu poreikis prisijungti prie tam tikros tarptautinès sutarties ar sudaryti naują tarptautinę sutartị bus objektyviai būtinas, gali atsitikti taip, kad bus peržiūrètos kai kurių Europos Sajungos teisès aktų taisyklès - to reikalauja koordinacinès teorijos, reglamentuojančios dviejų teisès sistemų suderinamumo nuostatas.

Pripažistant šių dviejų teisès sistemų savarankiškumą, galima išvengti jurisdikcinių konfliktų. Šiuo aspektu pažymètina Conndy byla prieš 15 valstybių Europos Sajungos narių ${ }^{26}$. Conndy, turẻdamas Europos Sajungos tarnautojo statusą, kritikavo Europos Sąjungos finansų politiką. Būtent dèl kritikos šio asmens atžvilgiu buvo pradèta drausminè procedūra Europos Komisijoje, vèliau ginčas persikèlè ị Europos Sajungos Pirmosios instancijos teismą bei Teisingumo Teismą. Conndy nesutiko su Europos Sajungos teismų sprendimais ir manė, kad buvo pažeistos Žmogaus teisių ir pagrindinių laisvių apsaugos konvencijos 6 straipsnio nuostatos, suteikiančios saviraiškos laisvę, bei kai kurie kiti konvencijos straipsniai. Peticijoje Conndy savotiškai išsprendẻ ginčo šalies klausimą, ịvardindamas ginčo šalimi (atsakovu) 15 Europos Sajungos valstybių narių - kurios yra ir Konvencijos šalys. Apibendrinant Strasbūro Teismo sprendimą, šioje byloje galima išryškinti šiuos momentus. Visų pirma, Teismas patvirtino tos pačios adekvačios žmogaus teisių apsaugos doktriną. Iš to galima daryti išvadą, kad Conndy ginčo atveju buvo suteikta reikiama žmogaus teisių apsauga. Antra, Teismas pažymëjo, kad ginčas liečia Europos Sajungą kaip supranacionalinę organizaciją bei jos institucijas - Europos Komisiją bei Europos Sajungos teismus. Trečia, Europos Sajungos valstybės, nors ir yra Konvencijos šalimis, negali būti atsakingos už galimus Europos Sajungos bei jos institucijų pažeidimus. Taigi ratione personae pagrindu peticija buvo atmesta.

26 Byla nebuvo nagrinèta Žmogaus Teisių Teisme ratione personae pagrindu, todèl sprendimas nepublikuotas. 
Analizuojant tarptautinės teisès ir Europos Sajungos teisès santykị reikia atkreipti dėmesị, kad šių teisès sistemų taikymo apimtys yra skirtingos. Tarptautinè teisé gali būti universali ir regioninè. Tuo tarpu Europos Sajungos teisè yra tik regioninè teisès sistema. Turint tai omenyje, gali kilti klausimas, kaip dažnai tarptautinès teisès normos taikomos Europos Sajungoje ir kaip dažnai Europos Sajungos teisès normos taikomos tarptautinèje teisèje? Pozityviosios teisès taikymo atvejai parodo, kad pirmasis atvejis pasitaiko gana dažnai, tuo tarpu antrasis atvejis - labai retas reiškinys. Tarptautinès teisés normų taikymas Europos Sajungos lygiu turi tendenciją augti. Keletas skaičių mums leidžia tuo įsitikinti. Apsiribojant tik tarptautiniais susitarimais, susijusiais su Europos Sajunga, statistiniai duomenys yra tokie: 1950-1974 metais buvo pasirašyta 18 tarptautinių susitarimų, 1975-2000 metais tokių susitarimų buvo 450, 2000-2010 metais tokių susitarimų skaičius viršijo $700^{27}$. Galima taip pat pastebėti, kad Europos Sajungos teismas neretai kaip tarptautinès teisès šaltinị taiko tarptautinius papročius ${ }^{28}$. Remiantis šiais duomenimis galima konstatuoti Europos Sajungos priartejjimą prie tarptautinės teisès.

Kadangi Europos Sajungos teisė yra regioninio pobūdžio, todèl jos taikymas universalioje teisès sistemoje, kokia yra tarptautinè teisè, yra ribotas. Galima pateikti keletą pavyzdžių, kada buvo pasiremta regionine teise. Antai, Tarptautinis Teisingumo Teismas pirmą kartą savo praktikoje davė nuorodą ị Europos žmogaus teisių ir pagrindinių laisvių apsaugos konvenciją, prie kurios planuoja prisijungti Europos Sajunga.

Labai ryškiai matomas Europos Sajungos santykis su tarptautine teise per vadinamąsias Europos Sajungos gaires. Antai, 2009 metais buvo atnaujintos Europos Sajungos gairès dèl skatinimo laikytis tarptautinès humanitarinès teisès ${ }^{29}$. Šių gairių tikslas nustatyti veiklos priemones, kuriomis Europos Sajunga ir jos institucijos bei organai skatintų laikytis tarptautinės humanitarinės teisės normų. Gairès skirtos visiems, kurie imasi su Europos Sajunga susijusių veiksmų, o iškilę klausimai priklauso jų atsakomybei ar kompetencijai. Gali kilti klausimas, ar minėtos gairès yra adresuotos Europos Sąjungos valstybėms narėms? Europos Sajungos valstybės narės yra pagrindinių tarptautinès humanitarinės teisès sutarčių šalimis ${ }^{30}$. Iš pirmo žvilgsnio atrodytų, kad šios gairès pirmiausia ir turètų būti skiriamos valstybėms narėms. Bet taip iš tikrujų nėra. Gairių 2 punkte tiesiogiai nurodoma, kad jos ES valstybėms narėms taikomos ne visa apimtimi. Šių gairių paskirtis yra visai kitokio pobūdžio. Pagrindinis gairių tikslas - gauti informaciją, taip pat išanalizuoti, kaip trečiosios valstybės laikosi tarptautinès humanitarinès teisès normų.

Šiomis gairėmis tarsi žymima, kad Europos Sajungos valstybės narès, kaip tarptautinès teisès subjektai, yra savarankiški, savo valia prisiima tarptautinius įsipareigojimus ir kaip subjektai atsako už sąžiningą tarptautinių įsipareigojimų vykdymą. Tarp tarp-

27 Žr. < http://europa.eu.int>, rubrique „Relations exterieures“.

28 Žr., pavyzdžiui, Europos Sąungos pirmosios instancijos teismo bylą Opel Austria T-115/94, Europos Sajungos Teisingumo Teismo bylą Brita C-386/08.

29 Europos Sajungos institucijų organų pranešimai. Taryba 2009/C303/06.

30 Visos Europos Sajungos valstybės narès, tarp jų ir Lietuvos Respublika, yra keturių Ženevos konvencijų, taip pat trijų papildomų protokolų prie Ženevos konvencijų šalys. 
tautinès teisès subjektų jokios subordinacijos nèra ir negali būti. Tarptautinè teisė savo esme yra koordinacinio pobūdžio teisè. Jeigu būtų kitaip, būtų pažeista visa tarptautinès teisès kaip koordinacinio pobūdžio teisès esmè.

Gairèse pažymima, kad Europos Sajungos misijų vadovai, Europos Sajungos civilinių ir karinių operacijų vadovai, Europos Sajungos specialieji igaliotiniai į savo ataskaitas apie atitinkamą valstybę ar konfliktą turi ịtraukti ir situacijos vertinimą tarptautinès humanitarinès teisės normų laikymosi požiūriu. Gairèse taip pat atkreipiamas dėmesys apie informacijos apie rimtus tarptautinès humanitarinès teisės pažeidimus svarbą.

Europos Sajungos Taryba yra prièmusi nemažai gairių ir išsakiusi poziciją žmogaus teisių kankinimo ir žiauraus elgesio, civilių asmenų apsaugos bei kitose srityse ${ }^{31}$.

Galètume prognozuoti, kad ateityje Europos Sajungos teisès ir tarptautinès teisès susisiekimo laukas pastebimai išsiplès. Todẻl ir ateityje bus aktualūs šių dviejų teisès sistemų santykio klausimai ir, be abejonès, dar labiau iškils šių dviejų teisės sistemų normų taikymo tiek apskritai, tiek teismuose problemos.

\section{Išvados}

Išstudijavus tarptautinès teisès ir Europos Sajungos teisès klausimą darytinos šios išvados:

1. Teisinis pliuralizmas gali pasireikšti ịvairiomis formomis ir lygiais. Teisiniam pliuralizmui sąlygas sudaro egzistuojančios ịvairios teisès sistemos. Šiuo metu galime konstatuoti, kad egzistuoja nacionalinių teisès sistemų įvairovė, taip pat savarankiškos tarptautinès teisès sistema ir Europos Sajungos teisès sistema. Šios trys teisès sistemos susisiekia, daro viena kitai poveikį. Taikant šių teisès sistemų normas neretai iškyla kolizinio pobūdžio problemų. Kuo didesnis šių teisès sistemų susisiekimo laukas, tuo aštriau kyla klausimas dẻl šių teisès sistemų santykio bei sąveikos.

2. Teisès doktrinoje plačiausiai išnagrinètas tarptautinės teisès ir nacionalinès teisès santykio klausimas. Šių dviejų teisès sistemų santykis dažniausiai aiškinamas per trijų teisès teorijų - monistinès, dualistinès ir koordinacinès - prizmę. Išanalizavus šias teorijas darytina išvada, kad kiekviena iš šių teorijų turi pranašumų ir trūkumų. Šių teorijų pagrindinès tezès yra koreguojamos, atsižvelgiant ị poreikius bei gyvenimo realijas. Šiuo metu, mūsų nuomone, populiariausia koordinacinè teorija.

3. Manytume, kad visos trys teorijos gali būti taikomos analizuojant tarptautinès teisès ir Europos Sajungos teisès santykio klausimą. Tačiau šių teorijų taikymas, mūsų nuomone, turi būti siejamas su realijomis. Teorijos taikymas yra naudingas, kai atneša

31 ES gairès dèl dialogų žmogaus teisių klausimais (patvirtintos Tarybos $2001 \mathrm{~m}$. gruodžio 13 d., atnaujintos 2009 m. sausio 19 d.); ES politikos dèl kankinimo ir kitokio žiauraus, nežmoniško ar žeminančio elgesio ar baudimo, susijusios su trečiosiomis šalimis, gairès (patvirtintos Tarybos $2001 \mathrm{~m}$. balandžio 9 d., atnaujintos $2008 \mathrm{~m}$. balandžio 29 d.); ES gairès dẻl vaikų ir ginkluotų konfliktų (patvirtintos Tarybos 2003 m. gruodžio 8 d., atnaujintos 2008 m. birželio 17 d.); ES gairès dèl vaiko teisių propagavimo ir apsaugos (patvirtintos Tarybos 2007 m. gruodžio 10 d.); ES gairès dèl smurto prieš moteris ir kovos su visų formų moterų diskriminacija (patvirtinta Tarybos $2008 \mathrm{~m}$. gruodžio 8 d.) ir $2003 \mathrm{~m}$. birželio 16 d. Tarybos bendroji pozicija 2003/444/BUSP dèl Tarptautinio baudžiamojo teismo. [2003] OL L150, 6 18, p. 67. 
praktinę naudą. Pavyzdžiui, konstatavę monistinės teorijos trūkumus, mes linkę pritarti nuomonei, kad valstybės, kuri yra Europos Sajungos narè, ar valstybės, kuri yra konkrečios tarptautinès sutarties šalis, viduje teisès taikymo prasme gali egzistuoti vieninga teisès sistema. Tą faktą patvirtina tiek Lietuvos Respublikos Konstitucija, tiek Lietuvos Respublikos konstitucinis aktas „Dèl Lietuvos Respublikos narystės Europos Sajungoje“ pažymint, kad Seimo ratifikuotos tarptautinès sutartys bei Europos Sajungos teisès normos yra sudedamosios Lietuvos Respublikos teisinès sistemos dalys. Mes pritariame dualistinès teorijos pagrindiniam teiginiui apie dviejų autonominių, savarankiškų Europos Sajungos teisès bei tarptautinès teisès sistemų egzistavimą. Tačiau Europos Sajungos teisès ir tarptautinės teisės santykyje turi išlikti šių teisės sistemų savarankiškumas. Europos Sajungos teisẻ santykyje su tarptautinès teisès sistema negali būti traktuojama kaip ,viršnacionalinè teisé“.

4. Tiek Europos Sajungos teisès aktuose, tiek Lietuvos Respublikos nacionalinejje teisèje galima surasti koordinacinės teorijos elementų santykyje tarp šių teisės sistemų ir tarptautinès teisès. Antai, Sutarties dèl Europos Sajungos veikimo 3 straipsnio 2 dalyje nurodyta, kad Sajunga naudojasi išimtine kompetencija tarptautiniams susitarimams sudaryti. Visos Europos Sajungos tarptautinių sutarčių sudarymo taisyklès patvirtina faktą, kad Europos Sajungos teisès aktai turi būti derinami su tarptautinès sutarties nuostatomis. Taigi, pripažindama tarptautinę sutartị teisiškai reikšminga, Europos Sajunga privalo suderinti savo teisės aktų nuostatas su tarptautine sutartimi. Šis reikalavimas atitinka koordinacinès teorijos, reglamentuojančios dviejų teisės sistemų suderinamumą, nuostatas.

5. Tarptautinès teisès ir Europos Sajungos teisès susisiekimo laukas nuolat plečiasi. Tai liudija straipsnyje pateikti duomenys apie Europos Sajungos sudaromas tarptautines sutartis - jų skaičius auga. Tarptautinès teisès ir Europos Sajungos teisès sąveika akivaizdžiai juntama per vadinamąsias Europos Sajungos gaires. Jos atkreipia dèmesi i tarptautinés teisės reguliuojamas aktualias problemas bei suteikia informaciją, kaip trečiosios valstybès laikosi tarptautinès teisès normų.

\section{Literatūra}

Byla 181/73 Haegeman v. Belgijos valstybe [1974] ECR 449, paras 5,6.

Byla C 344/04 IATA ir ELFAA [2006] Rink. 1-403, para 35.

Brounli, Ja. Mezdunarodnoje pravo. Kniga pervaja. Moskva, 1977, s. 69.

Case (6/64) Costa v. ENEL [1964] ECR 585.

Case (6/64) Costa v. ENEL [1964] ECR 585.

EJIL.Book Reviews. 2008, p. 875-878.

Europos Sajungos institucijų organų pranešimai. Taryba 2009/C303/06.

Europos Sajungos Pirmosios instancijos teismo byla Opel Austria T-115/94.
Europos Sajungos Teisingumo Teismo byla Brita C-386/08.

Sauer, H. Jurisdiktionskonfl ikte in Mehrebenensystemen: DieEntwicklung eines Modells zur Lösung von Konfl ikten zwischen Gerichten unterschiedlicher Ebenenin vernetzten Rechtsordnungen. Heidelberg: Springer, 2007.

$<\mathrm{http}$ ://europa.eu.int $>$, rubrique „Relations exterieures".

Jarukaitis, I. Europos Bendrijų teisès viršenybė ir valstybių narių bei Lietuvos Respublikos teisè. Teisé. 2000, 37: 46. 
Berg'e, J.-S. L'aplication die droit de l'lenion europenne et $d u$ droit international: de l'aplicabilite' a e 'invocabilite.

Jočienè, D. Europos žmogaus teisiu konvencijos taikymas. Vilnius: Eugrimas, 2001, p. 28.

Jočienè. D. Pagrindinių teisių apsauga pagal Europos žmogaus teisių konvenciją ir Europos Sajungos teisę. Jurisprudencija. 2010, 3(121): 17.

L'arret Hongrie c. Republique Slovaque du 16 October 2012, Affaire c.-364/10.

Jakulevičienè, L. Tarptautiniu sutarčiu teisé. Vilnius: Registrų centras, 2011, p. 381.

Mamontovas, A. Tarptautinių sutarčių bei ES teisès kolizijų sprendimas Europos Teisin- gumo Teismo praktikoje: teisiniai aspektai. Socialiniu moksly studijos. 2011, 3(1): 349.

Namavičius, Z. Suverenitetas ir Europos Sajungos teisé [interaktyvus]. [žiūrèta 2013]. $<$ http://www.lrkt.lt/PKonferencijose07.pdf $>$.

Aloupi, N. Les reports entredroit international et droit de L'union europenne. A propos du statut du chef d'Etat membre au regard de 1'arret Hogrie c. Republique Slovaque du 16 Octobre 2012. Revue generale de Droit international public. Tome CXVII. 2013, p. 7-35.

Vadapalas, V. Tarptautine teise. Vilnius: Eugrimas 2006, p. 50.

Victum, в. Г., et al. Mezhdunarodnoje pravo. Moskva, 2011, s. 36.

\title{
ON THE ISSUE OF RELATIONSHIP OF THE EUROPEAN UNION AND INTERNATIONAL LAW
}

\author{
Saulius Katuoka \\ Mykolas Romeris University, Lithuania
}

Summary. The paper analyses the relevant issue of the relationship of international law and European Union law. Therefore, independent systems of law exist, which inevitably arise the issue of relationship and interaction of these systems. Legal literature analyses the question of the relationship of these two systems of law on the basis of various aspects. The author has chosen the following structure of the paper: first, the general problem of the relationship of international and European Union law is discussed. While describing the problem, the nature of the European Union and international law, as well as the distinguishing features of these systems of law, is analysed. The paper also provides a discussion about the decisions of the Strasbourg court and the Court of Justice of the European Union, which provide the basis of solving the problem of the relationship of these systems of law. In the second part of this paper, the main theories are analysed: the monistic, dualistic and coordination theories, which can be used to answer the issue of interaction of the two systems of law-international law and European Union law.

Keywords: European Union law, international law, monist theory, dualist theory, coordination theory.

Saulius Katuoka, Mykolo Romerio universiteto Teisès fakulteto Tarptautinès ir Europos Sajungos teisès instituto direktorius, profesorius. Mokslinių tyrimų kryptys: tarptautinè jūrų teisè, tarptautinė viešoji teisè, Europos Sąungos teisè.

Saulius Katuoka, Mykolas Romeris University, Faculty of Law, Department of International and European Union Institute, Director, Professor. Research interests: international law of the sea, international public law, European Union law. 